\title{
Regulation of levels of purine biosynthetic enzymes in Bacillus subtilis: effects of changing purine nucleotide pools
}

\author{
Hans Henrik Saxild $\dagger$ and Per Nygaard* \\ University Institute of Biological Chemistry B, Solvgade 83, 1307 Copenhagen K, Denmark \\ (Received 25 April 1991; revised 11 June 1991; accepted 24 June 1991)
}

\begin{abstract}
The genes encoding the enzymes of IMP biosynthesis in Bacillus subtilis constitute the pur operon, whereas the genes encoding GMP biosynthetic enzymes, guaA (GMP synthetase) and guaB (IMP dehydrogenase), and the pur $A$ gene encoding adenylosuccinate (sAMP) synthetase all occur as single units. The pur $B$ gene encodes an enzyme involved in both IMP and AMP biosynthesis and is located in the pur operon. The levels of purine biosynthetic enzymes (except for GMP synthetase) were repressed in cells grown in the presence of purine compounds. Transcription of the pur operon is regulated negatively by adenine and guanine compounds. Our results suggest that ATP and guanine (or hypoxanthine) act as low molecular mass repressors. The level of IMP dehydrogenase was repressed by guanosine, but not in the presence of adenine, and was negatively correlated with the GTP/ATP pools ratio. The level of sAMP synthetase was repressed by adenine and increased by guanosine, and was positively correlated with the GTP/ATP pools ratio. It appears that the mode of regulating purine biosynthetic enzyme levels coincides with the cellular need for the individual enzymes.
\end{abstract}

\section{Introduction}

The Gram-positive bacterium Bacillus subtilis directs the formation of inosine monophosphate (IMP) via a tenstep pathway. IMP is then converted to AMP and GMP via two separate pathways, both comprising steps catalysed by two enzymes (Fig. 1). The purine geneenzyme relationship has been established in $B$. subtilis (Fig. 1; Ebbole \& Zalkin, 1987; Saxild \& Nygaard, 1988; Kanzaki \& Miyagawa, 1990). The purine genes are located at four different loci on the B. subtilis chromosome (Piggot \& Hoch, 1985). The genes encoding the enzymes of IMP biosynthesis comprise the pur operon, which consists of clusters of overlapping genes, purEKBpurCQLF-purMNH-purD. Transcription starts from a sigmaA-dependent promoter $242 \mathrm{bp}$ upstream of purE (Ebbole \& Zalkin, 1987). The gua A, guaB and purA genes occur as single units. The purine gene organization differs from that known in other micro-organisms. In Escherichia coli and Salmonella typhimurium the genes occur either as single units or small operons, which are

† Present address: Department of Microbiology, Technical University, DK-2800 Lyngby, Denmark.

Abbreviations: PRPP, 5-phosphoribosyl- $\alpha-1$-pyrophosphate; sAMP, adenylosuccinate. dispersed on the chromosome (Neuhard \& Nygaard, 1987).

In both B. subtilis (Momose et al., 1966; Nygaard et al., 1988) and enteric bacteria (Neuhard \& Nygaard, 1987) repressed levels of the purine biosynthetic enzymes are found when purine bases or nucleosides are present in the growth medium. Under these conditions purine synthesis de novo is reduced, and the preformed purines added to the growth medium are utilized for purine nucleotide synthesis. Purine auxotrophic mutants of $B$. subtilis show repressed levels of three of the enzymes of IMP biosynthesis, when grown with adenosine, guanosine or inosine. Furthermore, adenosine decreases the level of sAMP synthetase and guanosine decreases the level of IMP dehydrogenase (Nishikawa et al., 1967). Similar results, using pur gene fusions integrated in the pur operon, and representing genes of each of the clusters of the pur operon, were obtained by Ebbole \& Zalkin $(1989 a)$. These authors also provided evidence for the absence of internal promoters in the pur operon. Transcription of the pur operon is suggested to be regulated independently by adenine and guanine nucleotides (Ebbole \& Zalkin, 1987). The rate of transcription initiation is regulated by the interaction of a putative repressor protein, with a 116 nucleotide control region overlapping the -35 region of the pur promoter; the co- 


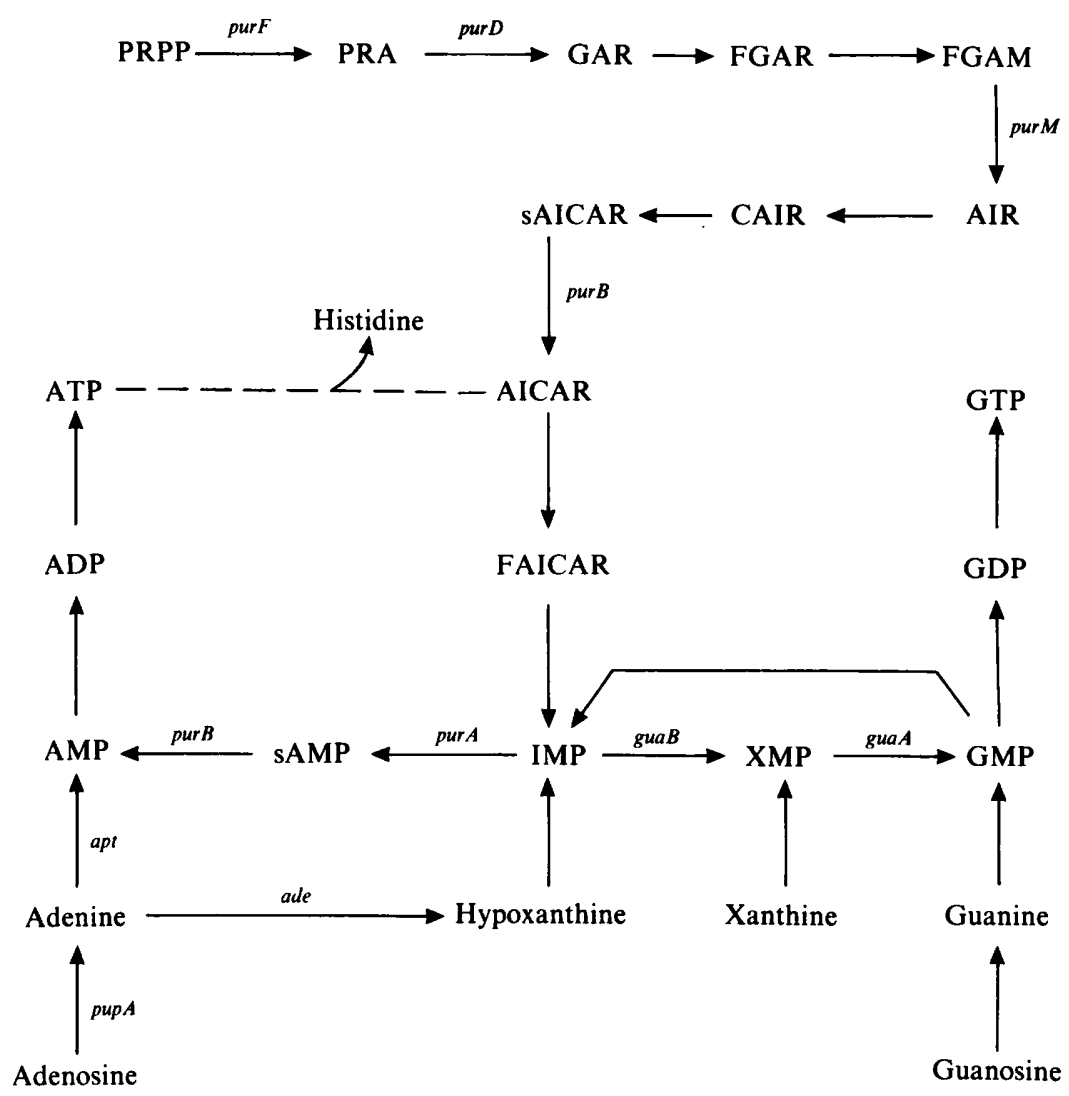

Fig. 1. Pathway of purine biosynthesis and interconversion in $B$. subtilis. Enzymes of relevance for the present study are identified by their gene symbols: purF, PRPP amidotransferase; purD, glycinamide ribonucleotide (GAR) synthetase; purM, aminoimidazole ribonucleotide (AIR) synthetase; purB, adenylosuccinate (sAMP) lyase; purA, sAMP synthetase; gua $B$, IMP dehydrogenase; guaA, GMP synthetase; apt, adenine phosphoribosyltransferase; ade, adenine deaminase; and pupA, adenosine phosphorylase. PRA, phosphoribosylamine; FGAR, formylglycinamide ribonucleotide; FGAM, formylglycinamidine ribonucleotide; CAIR, carboxyaminoimidazole ribonucleotide; sAICAR, aminoimidazolesuccinocarboxamide ribonucleotide; AICAR, aminoimidazolecarboxamide ribonucleotide.

repressor is probably an adenine compound. However, in vitro data could not show that the protein-DNA interaction depends on an adenine compound (Ebbole \& Zalkin, 1989b). The pur transcript contains a 242 nucleotide untranslated leader mRNA capable of forming a transcriptional terminator structure (Ebbole \& Zalkin, 1988). The transcriptional termination is regulated by a guanine compound and is believed to be mediated by a trans-acting factor involved in the formation of an antiterminator stem-loop structure in the mRNA leader region. No small molecular effector molecule has been identified.

In $E$. coli all purine genes, except for pur $A$, comprise a regulon that is regulated at the level of transcription initiation by the purR encoded repressor protein (PurR) (Meng et al., 1990). In vivo studies in S. typhimurium (Houlberg \& Jensen, 1983) and E. coli (Meng \& Nygaard, 1990) have provided evidence for guanine and hypoxanthine as small molecule repressors. In vitro analyses have demonstrated that the PurR protein, in the presence of guanine or hypoxanthine, is capable of binding to a specific nucleotide sequence (Meng \& Nygaard, 1990; Rolfes \& Zalkin, 1990). This sequence is found in the -35 region of purine biosynthetic genes ( $\mathrm{He}$ et al., 1990). The PurR protein has been shown also to repress the pyrC gene (dihydroorotase) of pyrimidine biosynthesis in S. typhimurium (Neuhard et al., 1990) and E. coli (Choi \& Zalkin, 1990; Wilson \& Turnbough, 1990). Involvement of GTP in expression of other genes of the pyrimidine biosynthesis pathway has also been observed (Jensen, 1989).

In the present paper, we describe how the levels of the enzymes of purine biosynthesis in B. subtilis are regulated to ensure a balanced supply of AMP and GMP. To explore the effect of various purine compounds on growth, enzyme levels and nucleotide pool size we have used wild-type cells, mutants defective in purine salvage and interconversion and purine auxotrophic mutants. 
Table 1. Bacillus subtilis strains used

\begin{tabular}{|c|c|c|}
\hline Strain & Genotype & Source or reference \\
\hline 168 & $\operatorname{trpC2}$ & C. Anagnostopoulos* \\
\hline OB-917 & $\operatorname{trpC2}$ hisAl thr-5 & R. A. Dedonder* \\
\hline PB3394 & metB5 purB26 & M. Chilton* \\
\hline 60077 & $\operatorname{trp} C 2$ hisB purM2 & Freese et al. (1979) \\
\hline 61857 & trpC2 met $B 4$ guaA2 & Freese et al. (1979) \\
\hline ED95 & ilvA1 sacA78 upp pupA3 & J. Neuhard $t$ \\
\hline ED157 & $\operatorname{trpC2}$ hisAl purM2 & $\ddagger$ Transformation of QB-917 by $60077, \mathrm{Thr}^{+}$and $\mathrm{Pur}^{-}$ \\
\hline ED160 & $\operatorname{trpC2}$ hisA1 purB26 & $\ddagger$ Transformation of QB-917 by PB3394, $\mathrm{Thr}^{+}$and Pur- \\
\hline ED234 & $\operatorname{trpC} 2$ hisAl guaA2 & Transformation of ED160 by $61857, \mathrm{Ade}^{+}$ \\
\hline ED250 & $\operatorname{trpC2}$ hisAl thr-5 purA2 & P. Duckert \\
\hline ED252 & trpC2 hisAl purHI adel & P. Duckert \\
\hline ED265 & $\operatorname{trpC2}$ adel & Transformation of ED252 by $168, \mathrm{Pur}^{+}$and $\mathrm{Thr}^{+}$ \\
\hline ED279 & trpC2 ade1 apt -7 & P. Nygaard \\
\hline ED287 & trpC2 hisAl apt-7 & \pm Transformation of $\mathrm{OB}-917$ by ED279, $\mathrm{Thr}^{+}$ \\
\hline
\end{tabular}

* Obtained through the Bacillus Genetic Stock Center, Ohio, USA.

† University Institute of Biological Chemistry B, Copenhagen, Denmark.

$\ddagger$ Transformation of the first strain with DNA from the second as described in Methods.

\section{Methods}

Bacterial strains and growth conditions. The bacterial strains used in this study are listed in Table 1. For enzyme analysis and nucleoside triphosphate and PRPP determinations cells were grown at $37^{\circ} \mathrm{C}$ in MOPS-buffered minimal medium (Freese et al., 1979), prepared with 2 mM-phosphate (Saxild \& Nygaard, 1987). The medium was supplemented with $50 \mu \mathrm{g}$ L-tryptophan, L-histidine and L-threonine $\mathrm{ml}^{-1}, 1 \mu \mathrm{g}$ thiamin $\mathrm{ml}^{-1}$ and with $1 \mathrm{~mm}$ of the stated purine compounds. Cells were grown exponentially, monitored by determining doubling time, for several generations to $\mathrm{OD}_{436}=0.8$ corresponding to $0.16 \mathrm{mg}$ dry wt bacteria $\mathrm{ml}^{-1}$ (Saxild \& Nygaard, 1987). Purine auxotrophic strains were starved for purine by transferring exponentially growing cells to purine free medium. At $\mathrm{OD}_{436}=0.8$ cells were washed and resuspended in pre-warmed purine-free medium and incubated for $90 \mathrm{~min}$ at $37^{\circ} \mathrm{C}$.

Transformation. Chromosomal DNA was isolated according to Young \& Wilson (1974). Transformation of B. subtilis strains was done according to the method of Boylan et al. (1972) as described previously (Saxild \& Nygaard, 1988).

Chemicals. Fine chemicals were purchased from Sigma. [ $\left.{ }^{32} \mathrm{P}\right] \mathrm{Ortho-}$ phosphate was from AEC Risø, Denmark, and ${ }^{14} \mathrm{C}$-labelled compounds were from Amersham.

Enzyme assays. Cells from $80 \mathrm{ml}$ of culture $\left(\mathrm{OD}_{436}=0.8\right)$ were harvested by centrifugation, washed in $0.9 \% \mathrm{NaCl}$, and stored overnight at $-20^{\circ} \mathrm{C}$. Preparation of cell-free extracts and determination of PRPP amidotransferase, glycinamide ribonucleotide synthetase, sAMP lyase, sAMP synthetase, IMP dehydrogenase and GMP synthetase activities were done as described previously (Saxild \& Nygaard, 1988). One enzyme unit (nkat) is defined as the amount of enzyme that converts 1 nmol substrate to product $\mathrm{s}^{-1}$. Enzyme levels are averages from at least three independent experiments, and are given as nkat (mg protein) ${ }^{-1}$.

Determination of nucleoside triphosphate and PRPP pools. [ $\left.{ }^{32} \mathrm{P}\right] \mathrm{Ortho}-$ phosphate $(0.8 \mathrm{MBq})$ was added to $2 \mathrm{ml}$ of exponentially growing cultures at $\mathrm{OD}_{436}=0.1$. At $\mathrm{OD}_{436}=0.8$, cells were extracted with formic acid, and the content of ATP, GTP and PRPP was determined by a two-dimensional chromatography method (Jensen et al., 1979). Pool levels are averages from at least three independent experiments.

\section{Results}

Effects of addition of purine compounds to wild-type cells

The effects of purines in the growth medium were monitored by determining levels of purine enzymes and purine nucleotide and PRPP pools. The enzymes which catalyse the branching from IMP to AMP and GMP (Fig. 1), and three enzymes representing different gene clusters within the pur operon ( $p u r B, p u r F$, purD) were studied. The technique used to measure nucleotide pools allows the determination of the eight nucleoside triphosphates and PRPP (Jensen et al., 1979).

Table 2 shows the effect of purine addition. Addition of adenine led to increased ATP pool size and diminished PRPP pool size, increased growth rate and decreased levels of sAMP synthetase (purA) and of the pur operon encoded enzymes. Guanosine addition led to increased GTP pool size and decreased levels of the enzymes corresponding to the pur operon and the guaB gene, while the level of sAMP synthetase (purA) was increased. Adenine and guanosine added together led to a more pronounced repression of the level of the pur operon encoded enzymes and decreased levels of sAMP synthetase (purA) and had no effect on the level of IMP dehydrogenase (guaB). Hypoxanthine stimulated growth and decreased the levels of the pur operon and guaB encoded enzymes, while xanthine had little effect on purine enzymes. The GMP synthetase (guaA) level was not influenced by purines.

\section{Effects of purine starvation on purine enzyme levels}

Mutants defective in the purine biosynthetic pathway either have a general or a specific purine requirement. 
Table 2. Effects of purines on pools of ATP, GTP and PRPP, and levels of purine biosynthetic enzymes in wild-type cells of $B$. subtilis

Strain QB-917 was grown and pools and enzyme levels analysed as described in Methods. Pools and enzyme levels are given as a percentage of values obtained in minimal medium (doubling time $50 \pm 4 \mathrm{~min}$ ). These values are averages \pm SD of eight independent experiments. Pool sizes [nmol (mg dry wt) ${ }^{-1}$ ] were as follows: ATP, $3 \cdot 3 \pm 0 \cdot 10 ;$ GTP, $0.98 \pm 0 \cdot 10 ;$ PRPP, $1 \cdot 13 \pm 0 \cdot 10$. Enzyme activities [nkat (mg protein) ${ }^{-1}$ ] were as follows: pur $A, 30 \cdot 0 \pm 4 \cdot 2 ;$ pur $B, 6180 \pm 480 ;$ purF, $696 \pm 66$; purD, $1212 \pm 66 ;$ guaA, $468 \pm 84 ;$ guaB, $606 \pm 102$.

\begin{tabular}{|c|c|c|c|c|c|c|c|c|c|}
\hline \multirow{2}{*}{$\begin{array}{l}\text { Purine added* } \\
\quad \text { (1 } \mathrm{mM})\end{array}$} & \multicolumn{3}{|c|}{ Relative pool size } & \multicolumn{6}{|c|}{ Relative enzyme level $\dagger$} \\
\hline & ATP & GTP & PRPP & purA & purB & purF & purD & guaA & guaB \\
\hline $\begin{array}{l}\text { Adenine } \\
\text { (49 min })\end{array}$ & 169 & 136 & 58 & 12 & 43 & 20 & 41 & 106 & 100 \\
\hline $\begin{array}{l}\text { Guanosine } \\
\text { (54 min) }\end{array}$ & 109 & 130 & 168 & 328 & 25 & 14 & 30 & 90 & 50 \\
\hline $\begin{array}{l}\text { Adenine }+ \\
\text { guanosine } \\
(47 \text { min })\end{array}$ & 170 & 126 & 59 & 10 & 6 & 6 & 6 & 82 & 114 \\
\hline $\begin{array}{l}\text { Hypoxanthine } \\
(48 \mathrm{~min})\end{array}$ & 100 & 104 & 101 & 86 & 32 & 22 & 34 & 94 & 73 \\
\hline $\begin{array}{l}\text { Xanthine } \\
(52 \mathrm{~min})\end{array}$ & 106 & 107 & 97 & 130 & 86 & 66 & 66 & 115 & 73 \\
\hline
\end{tabular}

* Times in parentheses after the name of the purine are doubling times.

$\dagger$ Enzymes are represented by their gene symbol (cf. Fig. 1).

Table 3. Effects of purine starvation on pools of ATP, GTP and PRPP, and levels of purine biosynthetic enzymes in strains of $B$. subtilis defective in purine biosynthesis

Cells were grown and pools and enzyme levels analysed as described in Methods. Pools and enzyme levels are given as a percentage of values from wild-type cells grown in minimal medium (doubling time $54 \mathrm{~min}$ ); cf. Table 2.

\begin{tabular}{|c|c|c|c|c|c|c|c|c|c|c|c|}
\hline \multirow[b]{2}{*}{ Strain } & \multirow{2}{*}{$\begin{array}{l}\text { Relevant } \\
\text { genotype }\end{array}$} & \multirow{2}{*}{$\begin{array}{l}\text { Purine } \\
\text { added* } \\
\text { (1 mM) }\end{array}$} & \multicolumn{3}{|c|}{ Relative pool size } & \multicolumn{6}{|c|}{ Relative enzyme level $\dagger$} \\
\hline & & & ATP & GTP & PRPP & purA & purB & purF & purD & guaA & guab \\
\hline ED250 & & None & 1 & 110 & 66 & $<1$ & 45 & 64 & 88 & 85 & 95 \\
\hline ED234 & guaA & $\begin{array}{c}\text { Guanosine } \\
\text { (52 min) }\end{array}$ & 104 & 121 & 157 & 349 & 20 & 16 & 38 & $<1$ & 63 \\
\hline \multirow[t]{2}{*}{ ED157 } & purM & $\begin{array}{l}\text { Adenine }+ \\
\text { guanosine } \\
\text { (54 min) }\end{array}$ & 160 & 121 & 57 & 18 & 6 & 4 & 4 & 72 & 118 \\
\hline & & None & 5 & 23 & 323 & 168 & 169 & 126 & 403 & 85 & 144 \\
\hline
\end{tabular}

* Times in parentheses after the name of the purine are doubling times.

† Enzymes are represented by their gene symbol (cf. Fig. 1).

Here we studied three mutants: strain ED157 (purM), which is defective in IMP biosynthesis (Fig. 1); a purA mutant (ED250), which requires adenine; and a gua $A$ mutant (ED234), requiring guanosine for growth. In the pur $A$ mutant, enzyme activities corresponding to the pur operon were repressed and the pool sizes of ATP and GTP were increased while the PRPP pool was diminished (Table 3). The major effect of adenine starvation was a diminished ATP pool size and some derepression of the level of the pur operon encoded enzymes. In the guaA mutant we found repressed levels of the pur operon and guaB encoded enzymes, increased levels of sAMP synthetase (purA) and increased pool sizes of GTP and PRPP. Guanosine starvation led to increased levels of IMP dehydrogenase (guaB) and diminished GTP pool size. To study the effect of starving the cells for both 
Table 4. Effects of adenine and adenosine on pools of ATP, GTP and PRPP, and levels of purine biosynthetic enzymes in strains of $B$. subtilis defective in purine salvage and interconversion

Cells were grown and pools and enzyme levels analysed as described in Methods. Pools and enzyme levels are given as percentage of values from wild-type cells grown in minimal medium (doubling time $54 \mathrm{~min}$ ); cf. Table 2.

\begin{tabular}{|c|c|c|c|c|c|c|c|c|c|}
\hline \multirow[b]{2}{*}{ Strain } & \multirow{2}{*}{$\begin{array}{l}\text { Relevant } \\
\text { genotype }\end{array}$} & \multirow{2}{*}{$\begin{array}{l}\text { Purine or } \\
\text { nucleoside } \\
\text { added* } \\
(1 \mathrm{mM})\end{array}$} & \multicolumn{3}{|c|}{ Relative pool size } & \multicolumn{4}{|c|}{ Relative enzyme level $\dagger$} \\
\hline & & & ATP & GTP & PRPP & purA & purB & purF & purD \\
\hline \multirow[t]{2}{*}{ ED265 } & ade & $\begin{array}{l}\text { None } \\
(52 \mathrm{~min})\end{array}$ & 101 & 101 & 89 & 152 & 103 & 99 & 119 \\
\hline & & $\begin{array}{l}\text { Adenine } \\
(66 \mathrm{~min})\end{array}$ & 123 & 82 & 56 & 13 & 50 & 55 & $\ddots^{66}$ \\
\hline \multirow[t]{2}{*}{ ED287 } & $a p t$ & $\begin{array}{l}\text { None } \\
(54 \mathrm{~min})\end{array}$ & 99 & 95 & 97 & 142 & 107 & 103 & $\therefore 112$ \\
\hline & & $\begin{array}{l}\text { Adenine } \\
\text { (54 min) }\end{array}$ & 96 & 92 & 104 & 151 & 80 & 87 & 97 \\
\hline \multirow[t]{2}{*}{ ED279 } & ade apt & $\begin{array}{l}\text { None } \\
\text { (54 min) }\end{array}$ & 99 & 102 & 80 & 243 & 96 & 73 & 97 \\
\hline & & $\begin{array}{l}\text { Adenine } \\
\text { (52 min })\end{array}$ & 98 & 105 & 107 & 253 & 83 & 74 & 94 \\
\hline \multirow[t]{3}{*}{ ED95 } & pupA & $\begin{array}{l}\text { None } \\
(54 \text { min) }\end{array}$ & 70 & 80 & 107 & 88 & 96 & 90 & 103 \\
\hline & & $\begin{array}{l}\text { Adenine } \\
(60 \mathrm{~min})\end{array}$ & 138 & 112 & 72 & 16 & 28 & 9 & 28 \\
\hline & & $\begin{array}{c}\text { Adenosine } \\
\text { (49 min) }\end{array}$ & 101 & 94 & 68 & 50 & 47 & 33 & 55 \\
\hline QB-917 & Wild-type & $\begin{array}{c}\text { Adenosine } \\
\text { (48 min) }\end{array}$ & 120 & 110 & 63 & 8 & 34 & 12 & 13 \\
\hline
\end{tabular}

- Times in parentheses after the name of the purine or nucleoside are doubling times.

$\dagger$ Enzymes are represented by their gene symbol (cf. Fig. 1).

adenine and guanine nucleotides, we shifted the purM mutant to purine-free medium. This led to increased levels of the enzymes encoded by the pur operon, the pur $A$ gene and the guaB gene. The pool sizes of ATP and GTP were reduced and that of PRPP increased (Table $3)$.

\section{Effects of adenine on purine enzyme levels in salvage mutants}

To determine whether adenine must be metabolized to affect purine gene expression, we studied the effects of adenine and adenosine in mutants defective in adenine phosphoribosylation (apt), adenine deamination (ade) and adenosine phosphorylase (pupA). Adenine had no significant effect on enzyme levels and pool sizes in the apt mutant. In the ade mutant, the sAMP synthetase (purA) level was markedly reduced and the pur operon expression was reduced to $50 \%$. The ATP pool was increased and the GTP and PRPP pools were decreased (Table 4). In the ade apt mutant elevated levels of sAMP synthetase, unaffected by adenine, were seen. Analysis of the pupA mutant, with reduced capacity for adenosine metabolism, revealed that the repressing effect of adenosine, but not the adenine effect, was significantly reduced (Table 4). This indicates that phosphorolysis of adenosine to adenine is required for maximal effect of adenosine.

\section{Discussion}

To understand the interaction between de novo synthesis of purines and purine salvage it is pertinent to recall that the two processes occur simultaneously, because purine bases and purine nucleosides are continuously formed and re-utilized (Nygaard, 1983). Exogenous purines are efficiently utilized for purine nucleotide synthesis. This has a sparing effect on purine synthesis de novo, and often stimulates growth (Table 2). During growth a balanced supply of adenine and guanine nucleotides is required. The mode of regulation of the purine biosynthetic pathway is mediated through feed-back inhibition mechanisms on central enzymes, and on the synthesis of purine biosynthetic enzymes (Neuhard \& Nygaard, 1987). Regulation of purine enzyme synthesis seems to be of significance only at higher concentrations of purine compounds in the growth medium. 


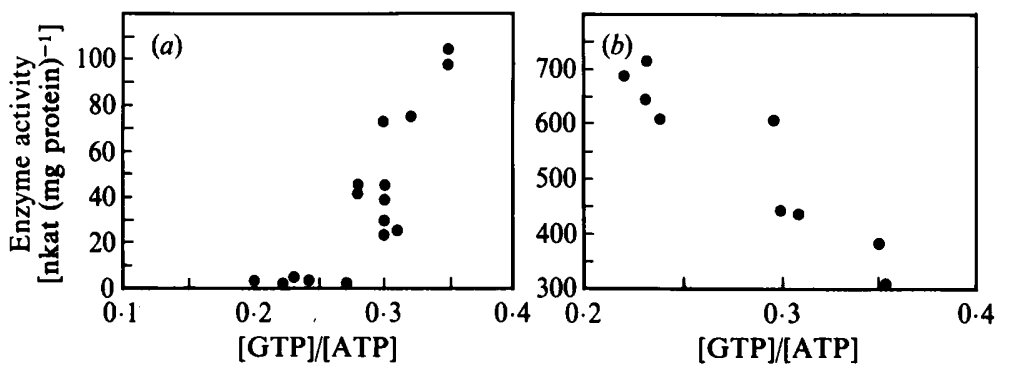

Fig. 2. Levels of sAMP synthetase and IMP dehydrogenase activity as a function of the GTP/ATP pools ratio. (a) Specific activity of sAMP synthetase (purA); (b) IMP dehydrogenase (guaB). Data from Tables 2, 3 and 4.
In the present study we used purines that, most likely, are present in the natural habitat of $B$. subtilis. Adenine and guanine compounds in a given habitat reflect cellular degradation, while hypoxanthine and xanthine compounds are excretion products. $B$. subtilis can utilize bases, nucleosides and nucleotides as sole purine source; adenine and hypoxanthine compounds serve equally well, guanine less well, and xanthine is a poor purine source (Nygaard, 1983). Because of the poor solubility of guanine in the culture medium, we have used only guanosine, which is converted to guanine inside the cell (Saxild \& Nygaard, 1987).

Addition of purines to cultures causes repressed levels of the pur $A$ and guaB encoded enzymes and the enzymes encoded by the pur operon (Tables 2, 3 and 4). Little is known, however, about regulation of the expression of the purA and guaB encoded enzymes at the transcriptional level. We could not find any clear correlation between enzyme levels and nucleotide pool sizes. However, when the levels of sAMP synthetase and IMP dehydrogenase were plotted versus the GTP/ATP pools ratio (Fig. 2), a positive correlation between increased GTP/ATP pools ratio and increased level of sAMP synthetase and decreased level of IMP dehydrogenase was observed. Accordingly, GTP increases and ATP decreases the level of sAMP synthetase while the reverse is true for IMP dehydrogenase. These changes in pools and enzyme levels clearly respond to the cellular need for AMP and GMP. The nucleoside triphosphates (ATP and GTP) are the major components of each nucleotide pool under exponential growth conditions, and they vary in parallel with the total nucleotide pools of adenine and guanine, respectively (Chapman \& Atkinson, 1977). Following growth on adenine the cells contained low concentrations of PRPP and increased ATP pools, while purine starvation led to increased PRPP pools and low ATP pools. Guanosine addition resulted in increased PRPP pool size. The PRPP pool size correlated positively with the GTP/ATP pools ratio. Whether PRPP is directly involved in the regulation of the expression of the purA and guaB genes remains to be established. The reduced PRPP pool size caused by adenine addition is caused, most likely, by the strong inhibiting effect of ADP on PRPP synthetase activity (Arnvig et al., 1990). By computer analysis, we could not find sequences in the upstream region of the guaB structural gene similar to those involved in the adenine and guanine control regions of the pur operon, suggesting a different mechanism of regulation of expression.

The expression of the pur operon has been studied in detail, and the current model (Zalkin \& Ebbole, 1989) suggests that transcription initiation is controlled by an adenine compound and that a guanine compound promotes early transcription termination. In agreement with this, we found throughout that the enzymes encoded by genes of the pur operon are affected by addition of adenine and guanosine to the growth medium, but we also observed that hypoxanthine addition represses these genes (Tables 2 and 3). No low molecular mass effector of purine gene expression in $B$. subtilis has been identified. In $E$. coli hypoxanthine and guanine appear to be low molecular mass repressors of purine gene expression (Meng \& Nygaard, 1990). We found that the expression of the pur operon was significantly influenced by addition of purines to the growth medium. Under most conditions the expression of the pur $B$ and the purD genes were co-ordinately regulated, except in purine-starved cells. The expression of the purF gene, encoding PRPP amidotransferase, was less well correlated with that of the other pur genes. This might be explained by the fact that PRPP amidotransferase is subject to in vivo degradation, particularly under starvation conditions (Grandoni et al., 1989). It is also possible that posttranscriptional regulation may affect the enzyme levels, as suggested for a purC-lac $Z$ translational fusion in $B$. subtilis (Ebbole \& Zalkin, 1989a). Instability during storage and assay could not account for the differences, because enzyme levels were not affected by storage of cells for up to 2 weeks at $-20^{\circ} \mathrm{C}$, and the extract did not lose activity when kept at $0^{\circ} \mathrm{C}$ for a number of hours (data not given). Neither individual nucleotide pools, nor any ratio between these correlate satisfactorily with pur operon enzyme levels. If we compare the pur operon levels exemplified by the purB enzyme versus the ATP pool size obtained in cultures that were not supplemented with guanosine or hypoxanthine, a correlation between 


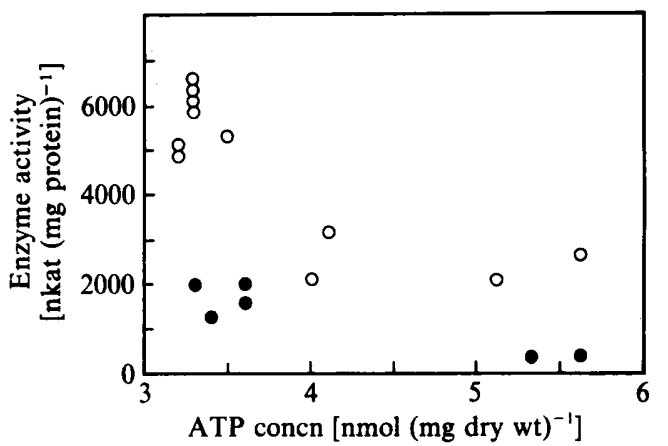

Fig. 3. Correlation between SAMP lyase activity and the ATP pool. The specific activity of sAMP lyase (purB) is plotted against the ATP pool. Data from Tables 2, 3 and 4; $\bigcirc$, data from experiments with cultures to which hypoxanthine or guanosine were added; $O$, data from other cultures.

enzyme and ATP pool size is seen (Fig. 3). Thus, in the absence of hypoxanthine and guanosine, we are determining enzyme levels regulated by the ATP pool size. This regulation, most likely, is mediated via an inhibition of the initiation of transcription, which is controlled by an adenine compound (Ebbole \& Zalkin, 1987). To account for the regulation of the pur operon expression under conditions where hypoxanthine or guanosine are present, we still have the ATP effect on initiation of transcription, and on top of that the regulation of transcription attenuation caused by a guanine compound; the highest level of repression is seen under conditions when the ATP pool is high and hypoxanthine or guanosine is present.

We measured purine enzyme levels in strains harbouring mutations that permit manipulation of the metabolism of adenine and adenosine (Table 4). Adenine affects pur gene expression (including the pur operon, pur $A$ and $g u a B$ ) only when it can be metabolized, giving rise to an increased ATP pool, and we believe this to be support for the above suggestions that ATP is a low molecular mass effector molecule, but the possibility remains that the effector may be AMP or ADP. Clearly a guanine nucleotide, probably GTP, plays a role in the regulation of the expression of the purA and guaB genes, but not of the pur operon. While it appears that the free bases guanine and hypoxanthine might be low molecular mass repressors of the pur operon, we found that the overall regulation of the level of purine biosynthetic enzymes shows a pattern that spares the synthesis of dispensable enzymes, with the exception of GMP synthetase (guaA).

We appreciate the technical help of Jenny Steno Christensen and Dr Kenneth Harlow for critical comments. The work received financial support from Novo's Fond.

\section{References}

Arnvig, K., Hove-Jensen, B. \& Switzer, R. L. (1990). Purification and properties of phosphoribosyl-diphosphate synthetase from Bacillus subtilis. European Journal of Biochemistry 192, 195-200.

Boylan, R. J., Mendelson, N. H., Brooks, P. \& Young, F. E. (1972). Regulation of the bacterial cell wall : analysis of a mutant of Bacillus subtilis defective in biosynthesis of teichoic acid. Journal of Bacteriology 110, 281-290.

Chapman, A. G. \& Atrinson, D. E. (1977). Adenine nucleotide concentrations and turnover rates. Their correlation with biological activity in bacteria and yeast. Advances in Microbial Physiology 15, 253-306.

CHOI, K. Y. \& ZALKIN, H. (1990). Regulation of Escherichia colipyrC by the purine regulon repressor protein. Journal of Bacteriology 172, 3201-3207.

EbBole, D. J. \& ZaLKIN, H. (1987). Cloning and characterization of a 12-gene cluster from Bacillus subtilis encoding nine enzymes for de novo purine nucleotide synthesis. Journal of Biological Chemistry 262, 8274-8287.

EBbOLE, D. J. \& ZALKIN, H. (1988). Detection of pur operon-attenuated mRNA and accumulated degradation intermediates in Bacillus subtilis. Journal of Biological Chemistry 263, 10894-10902.

EbBole, D. J. \& ZalKIN, H. (1989a). Bacillus subtilis pur operon expression and regulation. Journal of Bacteriology 171, 2136-2141.

EBBOLE, D. J. \& ZALKIN, H. (1989b). Interaction of a putative repressor protein with an extended control region of the Bacillus subtilis pur operon. Journal of Biological Chemistry 264, 3553-3561.

Freese, E., Heinze, J. E. \& Galliers, E. M. (1979). Partial purine deprivation causes sporulation of Bacillus subtilis in the presence of excess ammonia, glucose and phosphate. Journal of General Microbiology 115, 193-205.

Grandoni, J. A., Switzer, R. L., Makaroff, C. A. \& Zalkin, H. (1989). Evidence that the iron-sulfur cluster of Bacillus subtilis glutamine phosphoribosylpyrophosphate amidotransferase determines stability of the enzyme to degradation in vivo. Journal of Biological Chemistry 264, 6058-6064.

He, B., Shiau, A., Choi, K. Y., Zalkin, H. \& Smith, J. M. (1990). Genes of Escherichia coli pur regulon are negatively controlled by a repressor-operator interaction. Journal of Bacteriology 172, 45554562.

Houlberg, U. \& Jensen, K. F. (1983). Role of hypoxanthine and guanine in regulation of Salmonella typhimurium pur gene expression. Journal of Bacteriology 153, 837-845.

JENSEN, K. F. (1989). Regulation of Salmonella typhimurium pyr gene expression: effect of changing both purine and pyrimidine nucleotide pools. Journal of General Microbiology 135, 805-815.

Jensen, K. F., Houlberg, U. \& NygaARd, P. (1979). Thin-layer chromatographic methods to isolate ${ }^{32} \mathrm{P}$-labeled 5-phosphoribosyl- $\alpha$ 1-pyrophosphate (PRPP): determination of cellular PRPP pools and assay of PRPP synthetase activity. Analytical Biochemistry 98, 254263.

KanZaki, N. \& MiYagawa, K. (1990). Nucleotide sequence of the Bacillus subtilis IMP dehydrogenase gene. Nucleic Acids Research 18 , 6710.

Meng, L. M. \& NygaARd, P. (1990). Identification of hypoxanthine and guanine as the corepressors for the purine regulon genes of Escherichia coli. Molecular Microbiology 4, 2187-2192.

MeNG, L. M., KilsTRUP, M. \& NYGAARD, P. (1990). Autoregulation of PurR repressor synthesis and involvement of purR in the regulation of purB, purC, purL, purMN and guaBA expression in Escherichia coli. European Journal of Biochemistry 187, 373-379.

Momose, H., Nishikawa, H. \& SHIIO, I. (1966). Regulation of purine nucleotide synthesis in Bacillus subtilis. 1. Enzyme repression by purine derivatives. Journal of Biochemistry 59, 325-331.

NeUHARD, J. \& NygAaRd, P. (1987). Biosynthesis and conversion of nucleotides, purines and pyrimidines. In Escherichia coli and Salmonella typhimurium: Cellular and Molecular Biology, pp. 445473. Edited by F. C. Neidhardt, J. L. Ingraham, K. B. Low, B. Magasanik, M. Schaechter \& H. E. Umbarger. Washington, DC: American Society for Microbiology. 
Neuhard, J., Meng, L. M., Sørensen, K. \& Kelln, R. A. (1990). Purine control of pyrC expression in Salmonella typhimurium. International Journal of Purine and Pyrimidine Research 1, 61-66.

NishikaWA, H., Momose, H. \& SHIIO, I. (1967). Regulation of purine nucleotide synthesis in Bacillus subtilis. 2. Specificity of purine derivatives for enzyme repression. Journal of Biochemistry 62, 92-98.

NyGaARD, P. (1983). Utilization of preformed purine bases and nucleosides. In Metabolism of Nucleotides, Nucleosides and Nucleobases in Microorganisms, pp. 27-93. Edited by A. Munch-Petersen. London: Academic Press.

NygaARD, P., Duckert, P. \& SaXILD, H. H. (1988). Purine gene organization and regulation in Bacillus subtilis. In Genetics and Biotechnology of Bacilli, vol. 2, pp. 57-61. Edited by A. T. Ganesan and J. A. Hoch. New York: Academic Press.

Piggot, P. J. \& Hoch, J. A. (1985). Revised genetic linkage map of Bacillus subtilis. Microbiological Reviews 49, 158-179.

Rolfes, R. J. \& ZALKIN, H. (1988). Purification of the Escherichia coli purine regulon repressor and identification of corepressors. Journal of Bacteriology 172, 5637-5642.

SAXILD, H. H. \& NyGaARD, P. (1987). Genetic and physiological characterization of Bacillus subtilis mutants resistant to purine analogs. Journal of Bacteriology 169, 2977-2983.

SAXILD, H. H. \& NyGaARD, P. (1988). Gene-enzyme relationship of purine biosynthetic pathway in Bacillus subtilis. Molecular and General Genetics 211, 160-167.

WiLson, H. R. \& TURnbough, C. L. (1990). Role of the purine repressor in the regulation of pyrimidine gene expression in Escherichia coli. Journal of Bacteriology 172, 3208-3213.

Young, F. E. \& WiLson, G. A. (1974). Bacillus subtilis. In Handbook of Genetics, vol. 1, pp. 69-114. Edited by R. C. King. New York: Plenum Press.

ZalKIN, H. \& EbBole, D. J. (1988). Organization and regulation of genes encoding biosynthetic enzymes in Bacillus subtilis. Journal of Biological Chemistry 263, 1595-1598. 